\title{
PENGARUH SETTING RUANG TERBUKA TERHADAP SEBARAN TERITORI PKL DI WATERFRONT KOTA PONTIANAK
}

\author{
Yudithya Ratih ${ }^{1}$, Estar Putra Akbar ${ }^{2}$, Caesar Destria ${ }^{3}$ \\ ${ }^{1,3}$ Program Studi D4-Desain Kawasan Binaan, Politeknik Negeri Pontianak, Indonesia \\ ${ }^{2}$ Program Studi D4-Arsitektur Bangunan Gedung, Politeknik Negeri Pontianak, Indonesia
}

Penulis korespondensi: Estar Putra Akbar,Archi7estar@gmail.com

Naskah diajukan pada: 29 September 2020

Naskah revisi akhir diterima pada: 29 Maret 2021

\begin{abstract}
Abstrak
Pontianak waterfront city merupakan salah satu program yang terus dilakukan oleh pemerintah Kota Pontianak. Salah satu kawasan waterfront yang menarik untuk dikunjungi adalah kawasan Waterfront Seng Hie. Keberadaan waterfront Seng Hie memberikan dampak yang positif membantu meningkatkan citra Kota Pontianak sebagai Kota Tepian air, disisi lain ternyata memberikan dampak negatif, yaitu menjadi magnet kegiatan PKL yang tidak terencana sebelumnya. Kondisi ini jika tidak mendapat perhatian khusus, maka berpotensi munculnya konflik penggunaan ruang antara pengunjung dan para PKL. Penelitian ini bertujuan untuk mengetahui faktor-faktor Setting ruang yang mempengaruhi pola sebaran teritori PKL di Waterfront Kota Pontianak. Secara umum, hasil penelitian ini akan menjadi masukan Pemerintah Kota Pontianak dalam upaya memperbaiki kualitas ruang terbuka di tepian air dan akan bersinergi dengan keberadaan PKL. Metode digunakan dalam penelitian ini adalah pemetaan perilaku, yang akan terkait dengan variabel Setting ruang. Hasil penelitian ini ditemukan faktor utama yang mempengaruhi pola distribusi PKL di Waterfront Kota Pontianak yaitu keberadaan seting Fix di waterfront seperti Pagar, Bangku Taman, Perkerasan Beton yang menjadi media PKL untuk berjualan, yang dibedakan atas lima pola teritori sebaran PKL (1) disekitar bangku taman, 2) di sekitar plaza, 3) di sekitar pagar, 4) di sekitar reling tangga, 5) di sekitar anak tangga.
\end{abstract}

Kata-kata Kunci : Seting, Ruang Terbuka, Teritori, PKL, Waterfront

\section{THE EFFECT OF SETTING OPEN SPACE ON THE SPREAD OF PKL TERRITORY IN THE WATERFRONT OF PONTIANAK CITY}

\begin{abstract}
Pontianak waterfront city is one of the programs that the Pontianak City government continues to carry out. One of the interesting waterfront areas to visit is the Seng Hie Waterfront area. The existence of Seng Hie's waterfront has a positive impact helping to improve the image of Pontianak City as a waterfront city; on the other hand, it has a negative effect, namely becoming a magnet for previously unplanned street vendors activities. If this condition does not get special attention, then the potential for conflict in the use of space between visitors and street vendors. This study aims to determine the spatial setting factors that affect the distribution patterns of street vendors at the Waterfront of Pontianak City. In general, the results of this research will be used as input for the
\end{abstract}


Pontianak City Government to improve the quality of open spaces on the water's edge. They will synergize with the existence of street vendors. The method used in this research is behavior mapping, which will be related to the variable space setting. The results of this study found that the main factors that influence the distribution pattern of street vendors at the Waterfront of Pontianak City are the presence of Fix settings on the waterfront such as fences, park benches, concrete pavers which become the media for street vendors to sell, which are divided into five territorial patterns of street vendors (1) around park benches, 2) around the plaza, 3) around the fence, 4) around the stair rail, 5) around the steps.

Keywords: Setting, Open Space, Territory, Street Vendors, Waterfront

\section{Pendahuluan}

Kota Pontianak sebagai Kota Tepian Air merupakan image atau citra kota yang ingin ditampilkan oleh pemerintah Kota Pontianak sesuai dengan Perda RTRW Kota Pontianak Tahun 2013-2033 (Perda, 2013), dan kota tepian air itu sendiri merupakan cikal bakal embrio sejarah perkembangan Kota Pontianak. Salah satu upaya yang dilakukan untuk mewujudkan hal tersebut pemerintah Kota Pontianak melakukan penataan kawasan yang ada di tepian Sungai Kapuas menjadi area ruang publik sejak 2016. Mulai dari Tambelan Sampit Pontianak Timur dan sekarang yang baru saja rampung di sepanjang tepian sungai yang berbatasan dengan pelabuhan Seng Hie Pontianak.
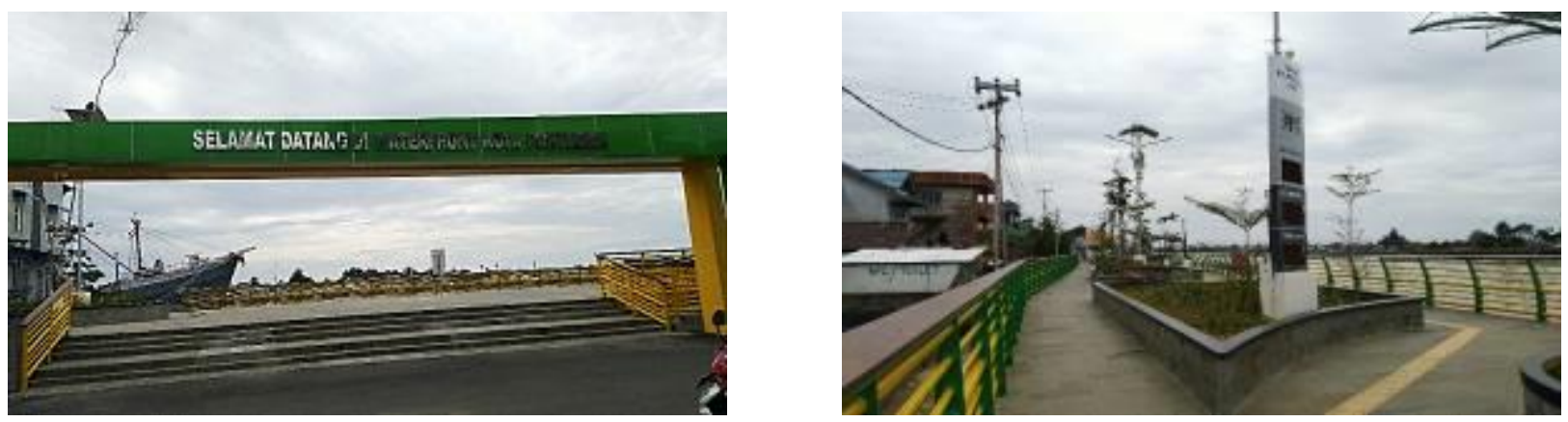

Gambar 1. Waterfront Seng Hie Kota Pontianak Sumber: Survey, 2019

Dengan dibukanya kawasan waterfront ini memunculkan suatu magnet baru kegiatan informal yaitu munculnya para pedagang kaki lima (PKL). Kondisi eksisting di area waterfront Kota Pontianak yang ada saat ini memang tidak memiliki Area yang secara khusus untuk para PKL untuk berjualan. Berdasarkan pengamatan di lapangan terlihat munculnya perilaku masyarakat sekitar untuk mengisi ruang-ruang terbuka yang ada sebagai kegiatan usaha sewa permainan anak dan berjualan (makanan, minuman dan mainan anak-anak) di sepanjang area waterfront. Kondisi PKL yang ada saat ini dapat dikatakan muncul secara sporadis di beberapa area waterfront tidak terencana pada desain awalnya. Munculnya kegiatan PKL ini satu sisi dapat meningkatkan perekonomian masyarakat sekitar area waterfront dan warga Kota Pontianak dan disisi lain dapat memberikan dampak yang kurang baik jika hal ini tidak mendapat perhatian yang dari pemerintah Kota Pontianak untuk segera dikelola dan ditata dengan baik, karena berpotensi menimbulkan dampak tidak baik pada setting ruang terbuka jika para PKL tidak segera diatur atau ditata keberadaan. Diharapkan keberadaan para PKL diruang terbuka ini dapat difasilitasi secara optimal sehingga menjadi bagian dari aktivitas di Ruang Terbuka di tepian air. 
Untuk itu perlu suatu arahan setting ruang terbuka dari waterfront yang ada, untuk dapat memfasilitasi kegiatan para PKL sehingga kawasan waterfont menjadi lebih ramah lingkungan dan lebih manusiawi dan tertata dengan baik. Riset ini sebagai langkah awal untuk melihat faktor apa saja yang mempengaruhi sebaran teritori para PKL yang ada di waterfront Kota Pontianak. Rumusan masalah pada penelitian ini adalah faktor-faktor setting ruang apa saja yang mempengaruhi pola sebaran teritori PKL di Waterfront Kota Pontianak.

\section{Ruang Terbuka}

Ruang terbuka yang berasal dari kata open space, open yang berarti terbuka, bebas, ataupun di luar rumah. Space yang berarti ruang, tempat, daerah. (Echols, 2005) Jadi ruang terbuka (open space) adalah tempat yang berada di daerah terbuka secara bebas (ruang luar).

Dan ruang terbuka sendiri akan memiliki batasan ruang yang tercipta oleh tatanan bangunan, yaitu (Ching, 2000) :

1. Ruang horizontal dibatasi oleh permukaan jalan (tanah, perkerasan) dan kanopi dari bangunan.

2. Ruang vertikal dibatasi oleh dinding dari bangunan yang biasanya terdapat di kiri dan kanan dan membentuk sebuah koridor, batasan vertikal ini juga dapat terbentuk dari elemen landscape seperti pohon-pohon, lampu taman, dll.

3. Rasio ukuran, bentuk permukaan, orientasi dan posisi sangat ditentukan dari massa bangunan yang ada.

Menurut teori figure-ground (Trancik, 1986) mengatakan: pemahaman bentuk ruang kota diawali dengan analisis hubungan antara massa bangunan dan ruang terbuka (solid dan void). Daerah yang tidak terdapat bangunan akan di sebut sebagai void sedangkan daerah terbuka akan yang ada di sekitar bangunan disebut dengan solid. Ruang terbuka merupakan bagian pembentuk wajah kota, maka antara pola solid (bangunan) dan void (ruang terbuka) menjadi satu kesatuan unsur yang tidak dapat terpisahkan.

Secara umum terdapat unsur mendasar dalam identifikasi tipe dari tata ruang menurut Hall, 1966 (dalam Lang, 1987), (Rapoport, 1982) :

1. Fixed-feature space, misalnya dinding solid, lantai, jendela; bentukan yang sulit untuk berubah.

2. Semifix-feature space, misalnya perabot meja kursi; bentukan yang mudah untuk berubah atau sifatnya tidak tetap.

3. Informal space(non-fix), yaitu ruang yang terjadi di luar kesadaran (aktivitas) dalam jangka waktu tertentu.

Ketiga elemen ini akan dilihat pada kawasan waterfront Seng Hie, terkait apa saja elemen setting fisik yang mempengaruhi sebaran PKL.

\section{Kawasan Tepian Air}

Kawasan Tepian air atau Waterfront dalam Bahasa Indonesia berarti daerah tepi laut, bagian kota yang berbatasan dengan air, daerah pelabuhan (Echols, 2005). Sedangkan, urban waterfront mempunyai arti suatu lingkungan perkotaan yang berada di tepi atau dekat wilayah perairan, misalnya lokasi di area pelabuhan besar di kota metropolitan (Wrenn dalam Soesanti, 2006). Dari pengertian tersebut waterfront dapat didefinisikan sebagai suatu daerah atau area yang terletak dekat/berbatasan dengan kawasan perairan ataupun sungai yang terdapat satu atau beberapa kegiatan dan aktivitas pada area pertemuan tersebut.

Definisi lainnya terkait kawasan tepi air (Suprijanto, 2003) :

1. Kawasan yang dinamis dan unik dari suatu kota (dengan segala ukuran) di mana daratan dan air (sungai, danau, laut, teluk) bertemu (kawasan tepian air) dan harus dipertahankan keunikannya. 
2. Kawasan yang dapat meliputi bangunan atau aktivitas yang tidak harus secara langsung berada di atas air, akan tetapi terikat secara visual atau historis atau fisik atau terkait dengan air sebagai bagian dari "scheme" yang lebih luas.

Dapat disimpulkan kawasan tepian air adalah daerah yang berbatasan dengan air yang digunakan untuk aktivitas keseharian (interaksi sosial) dari masyarakat kota tentunya, yang pada kasus amatan penelitian ini adalah para Pedang Kaki Lima (PKL).

\section{Setting Perilaku}

Barker (dalam Laurens, 2004), Behavioral setting disebut juga dengan "tata perilaku" yaitu pola perilaku manusia yang berkaitan dengan tatanan lingkungan fisiknya. Sejalan dengan apa yang disampaikan oleh Haviland (dalam Laurens, 2004) bahwa tata perilaku sama dengan "ruang aktivitas" untuk menggambarkan suatu unit hubungan antara perilaku dan lingkungan bagi perancangan arsitektur. Selain itu juga Heimstra dan McFarling's, (dalam Bell, 1996) mengatakan bahwa studi hubungan behavior (perilaku) dan physical environment (lingkungan fisik) merupakan usaha untuk membangun berdasarkan pengalaman (establish empirical) dan teori hubungan antara perilaku dan pengalaman seseorang terhadap lingkungan yang terbangun.

Barker, 1968 (dalam Lang, 1987) mendefinisikan Behavior Setting terdiri atas kombinasi aktifitas (activity) dan tempat (Place) yaitu:

1. A recurrent activity (aktivitas).

2. A particular layout of the environment (setting Ruang).

3. A specific time period (waktu).

4. Synomorphy yaitu membentuk suatu hubungan yang sesuai dan berkaitan.

Activity systems lingkungan terdiri dari hirarki behavior setting yang terhubung bersama dengan bentuk suatu sistem aktivitas. Merupakan kegiatan manusia/People activity systems yang mencerminkan motivation/motivasi, attitudes/sikap, and knowledge/pengetahuan/yang dipahami mengenai gambaran dunia dalam batasan dari incomes/masukan, competencies/kompetensi, cultural norm/ normal budaya (Chapin and Brail 1969, Porteous 1977 dalam Lang, 1987).

Jika bicara atribut yang harus dipenuhi sebuah entitas untuk menjadi sebuah behavioral setting maka akan terdiri atas (Laurens, 2004):

1. Aktivitas

2. Penghuni

3. Kepemimpinan, untuk mengetahui posisi fungsional penghuni, untuk mengetahui peran sosialnya yang ada di dalam komunitas tersebut

4. Populasi, sebuah setting dapat mempunyai banyak atau sedikit partisipan. Komunitas dianggap lebih baik apabila memiliki banyak setting.

5. Ruang, tempat terjadinya setting tertentu sangat beragam, bisa diruang terbuka atau tertutup

6. Waktu, kelangsungan sebuah setting dapat terjadi secara rutin atau sewaktu-waktu. Durasi setting yang sama dapat berlangsung sesaat atau terus-menerus sepanjang tahun.

7. Objek

8. Mekanisme Perilaku

\section{Teritori}

Setiap spektrum mempunyai batas area tersendiri dikenal sebagai teritori (Hariyadi, 2010). Lebih lanjut Altman,1975( dalam Lang, 1987) Perilaku Teritori berati suatu mekanisme diri sendiri berupa membuat batasan yang menyebabkan munculnya personalisasi dengan menandai tempat atau objek dan mengkomunikasikan bahwa ini dimiliki seseorang ataupun sekelompok orang. Penanda teritori dapat berupa (Lang, 1987) batasan fisik dan penanda simbolik. Lebih lanjut disebutkan karakteristik dari teritori terdiri atas (Lang, 1987) :

1. Adanya kepemilikan atau penggunaan untuk suatu tempat. 
2. Adanya Personalisasi ataupun memberi penanda area.

3. Kemampuan untuk mempertahankan dari gangguan.

4. Memenuhi kebutuhan Psikologis dasar hingga kepuasan kebutuhan kognitif dan estetika.

Lebih lanjut ditambahkan bahwa teritori dalam kajian Arsitektur Lingkungan dan Perilaku (Laurens, 2004) memuat beberapa hal yaitu :

1. Adanya batasan

2. Ditandai

3. Dipertahankan

Sehingga ke tujuh aspek tersebut perlu untuk menjadi pertimbangan utama dalam pengamatan perilaku dalam arsitektur.

\section{Metode}

Penelitian ini akan dilaksanakan selama enam bulan. Waktu pelaksanaan penelitian dari bulan Juni tahun 2019 sampai dengan bulan Desember tahun 2019. Sedangkan lokasi penelitiannya adalah Waterfront Kota Pontianak yang berada di tepian Sungai Kapuas yang sejajar dengan Jl. Tanjungpura Pontianak Sepanjang $\pm 800 \mathrm{~m}$, dengan gerbang masuk utama berada di Pelabuhan Seng Hie Pontianak dan alternatif masuk lainnya dari arah Gg. Irian Jl Tangjungpura.

Pengumpulan data dilakukan dengan metode observasi lapangan, wawancara dan kuesioner, dan behavior mapping melalui sketsa-sketsa dan identifikasi secara langsung di lapangan. Observasi lapangan dilakukan untuk menggali data-data berupa pemetaan lokasi ruang-ruang terbuka tempat berkumpul PKL terkait data sebarannya, mengidentifikasi setting ruang berkumpul terkait teritori Place Centered Mapping dan melihat pola aktivitas para PKL dengan Metode Person Centered Mapping. Wawancara dan kuesioner dilakukan untuk menggali informasi yang tidak dapat dilihat secara langsung, seperti pendapat pribadi atau harapan-harapan dari pelaku.

Variabel penelitian yang digunakan pada penelitian ini terdiri dari variabel bebas yaitu setting Ruang Terbuka dan Variabel terikat yaitu teritori.

Tabel 1. Variabel Penelitian

\begin{tabular}{|c|c|c|c|c|}
\hline No & Variable & Parameter & Indikator & Metode \\
\hline \multirow{4}{*}{1} & \multirow{4}{*}{$\begin{array}{l}\text { Variabel } \\
\text { Bebas } \\
\text { (Setting } \\
\text { Ruang) }\end{array}$} & Setting Ruang & & \\
\hline & & Fix & $\begin{array}{l}\text { Penggunaan semua elemen yang } \\
\text { sifatnya sulit untuk berubah atau } \\
\text { tetap (Pohon, tangga, Perkerasan, } \\
\text { dsb.) }\end{array}$ & $\begin{array}{l}\text { - Observasi,Behavior Mapping, } \\
\text { Wawancara }\end{array}$ \\
\hline & & Semi Fix & $\begin{array}{l}\text { Penggunaan semua elemen yang } \\
\text { sifatnya tidak tetap atau fleksibel } \\
\text { mudah berubah (Bangku, Meja, } \\
\text { dsb) }\end{array}$ & $\begin{array}{l}\text { - Observasi,Behavior Mapping, } \\
\text { Wawancara }\end{array}$ \\
\hline & & Non Fix & $\begin{array}{l}\text { Ruang yang terbentuk karena } \\
\text { aktivitas seperti berkumpul }\end{array}$ & $\begin{array}{l}\text { - Observasi,Behavior Mapping, } \\
\text { Wawancara }\end{array}$ \\
\hline \multirow[b]{3}{*}{2} & \multirow{3}{*}{$\begin{array}{l}\text { Variabel } \\
\text { Terikat } \\
\text { (Teritori) }\end{array}$} & Teritorialitas PKL & & \\
\hline & & Kepemilikan/batasan & $\begin{array}{l}\text { Individu, Berkelompok, Elemen } \\
\text { pembatas ruang }\end{array}$ & $\begin{array}{l}\text { Observasi,Behavior Mapping, } \\
\text { Wawancara }\end{array}$ \\
\hline & & Personalisasi/ditandai & Penanda Area & $\begin{array}{l}\text { Observasi,Behavior Mapping, } \\
\text { Wawancara }\end{array}$ \\
\hline
\end{tabular}

Mempertahankan dari Mekanisme mempertahankan $\quad \begin{aligned} & \text { - Observasi,Behavior Mapping, } \\ & \text { Wawancara }\end{aligned}$




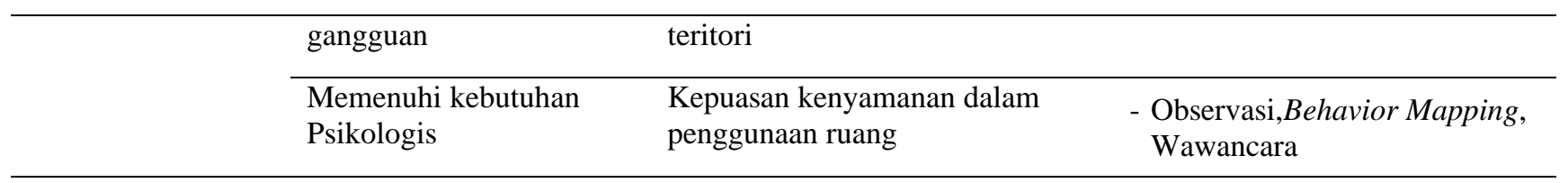

\section{Sumber: Penulis, 2019}

\section{Hasil dan Pembahasan \\ Place Centered Mapping}

Berdasarkan hasil pengamatan Zona A-D dengan metode Place Centered Mapping didapatkan data sebagai berikut:

Tabel 2. Place Centered Mapping Zona A, B, C, D

\section{Place Centered Mapping}

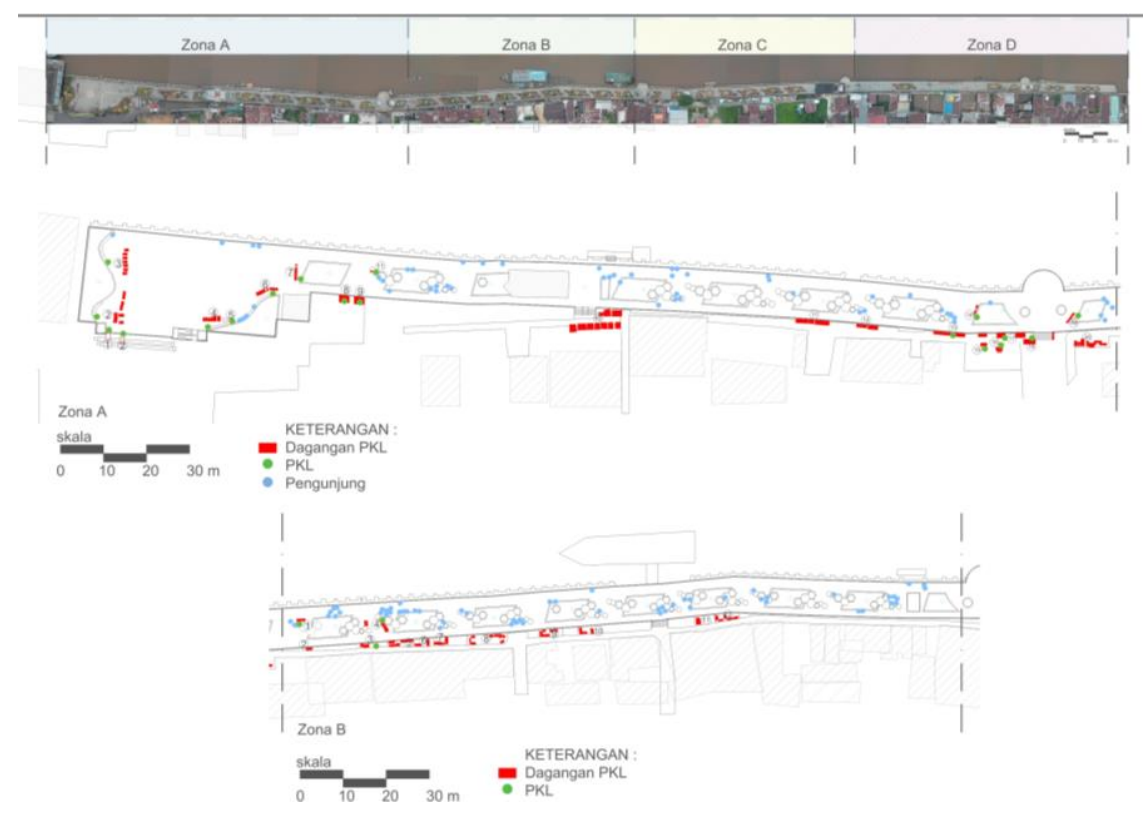

1) Zona A, yang merupakan gerbang masuk utama terdiri atas PKL dengan karakter jualan yaitu : Makanan Ringan dan minuman, Sewa mainan, dan Gorengan. Beberapa PKL menempati area Plaza sebagai tempat berjualan dan duduk di bangku taman dan sebagian mengambil tempat disisi luar waterfront yang berbatasan di area darat.

2) Zona B, karakter jualan yaitu Makanan Ringan dan minuman , Sewa mainan, dan Gorengan. PKL makanan dan gorengan yang berada di sisi luar waterfront yaitu arah darat mulai mendominasi sepanjang waterfront dengan pola yang tersebar. Hanya terdapat beberapa PKL menggunakan area tengah/bangku taman untuk area sewa mainan.

3) Zona C, yang merupakan bagian tengah kawasan terdiri atas PKL dengan karakter jualan yaitu : Makanan Ringan dan minuman, Sewa mainan, dan Gorengan. PKL makanan dan gorengan yang berada di sisi luar waterfront yaitu arah darat sepanjang waterfront dengan pola yang mulai mengumpul pada satu area dan merupakan PKL terbanyak di antara zona A, B, dan D.

4) Zona D, yang merupakan bagian ujung kawasan terdiri atas PKL dengan karakter jualan yaitu : Makanan Ringan dan minuman, Sewa mainan, dan Gorengan. PKL makanan dan gorengan yang berada di 
sisi luar waterfront yaitu arah darat sepanjang waterfront dengan pola yang mulai mengumpul pada satu area tetapi tidak sebanyak di Zona C.

Sumber: Penulis, 2019

\section{Person Centered Mapping}

Tabel 3. Person Centered Mapping Zona A, B, C, D

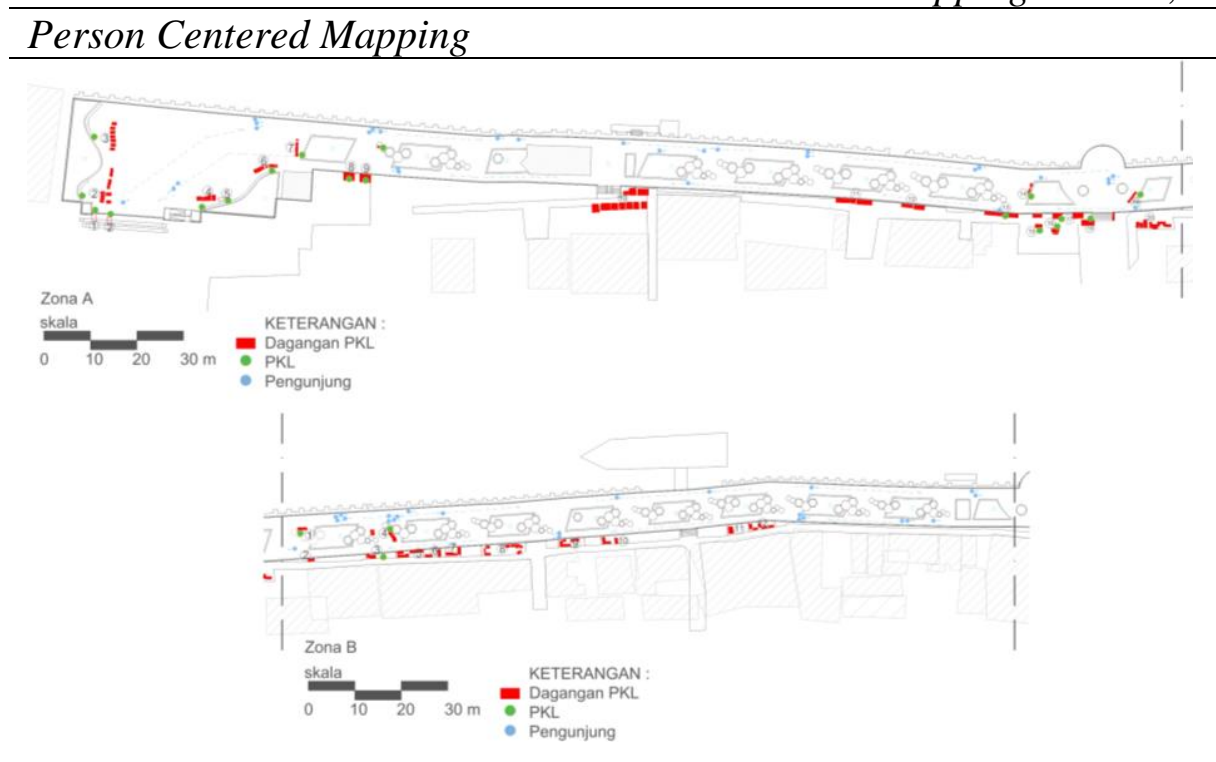

1) Zona A menunjukkan Pergerakan pengunjung yang datang dari pintu gerbang utama waterfront melewati plaza utama yang kemudian bergerak menyisiri tepian sungai (dekat pagar sisi sungai) dan pergerakan pulang melewati sisi pagar darat

2) Zona B, pergerakan pengunjung yang datang menunjukkan bahwa, pengunjung bergerak menyisiri sisi pagar waterfront arah sungai dan pulang menelusuri sisi pagar arah darat.

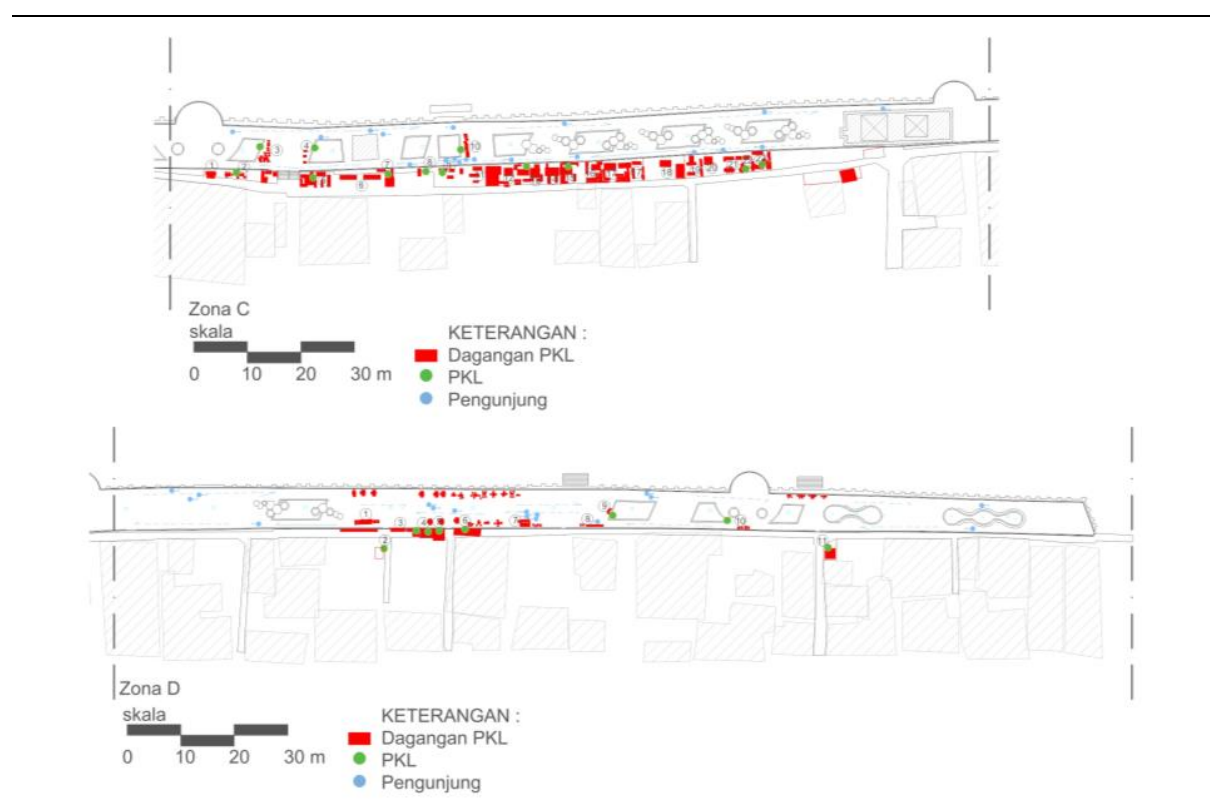

3) Zona C, pergerakan pengunjung yang datang menunjukkan bahwa, pengunjung bergerak menyisiri sisi pagar waterfront arah sungai dan pulang menyisiri pagar arah darat.

4) Zona D, pergerakan pengunjung yang datang menunjukkan bahwa, pengunjung bergerak menyisiri sisi pagar waterfront arah sungai dan pulang menyisiri pagar arah darat.

Sumber: Penulis, 2019

\section{Setting Waktu}

Berdasarkan hasil pengamatan yang dilakukan maka didapatkan bahwa intensitas PKL terbesar didominasi pada waktu Sore hari sampai malam yaitu sekitar Pukul 16.00 sampai 23.00. Berikut ini adalah sebaran intensitas PKL berdasarkan periode Waktu : 


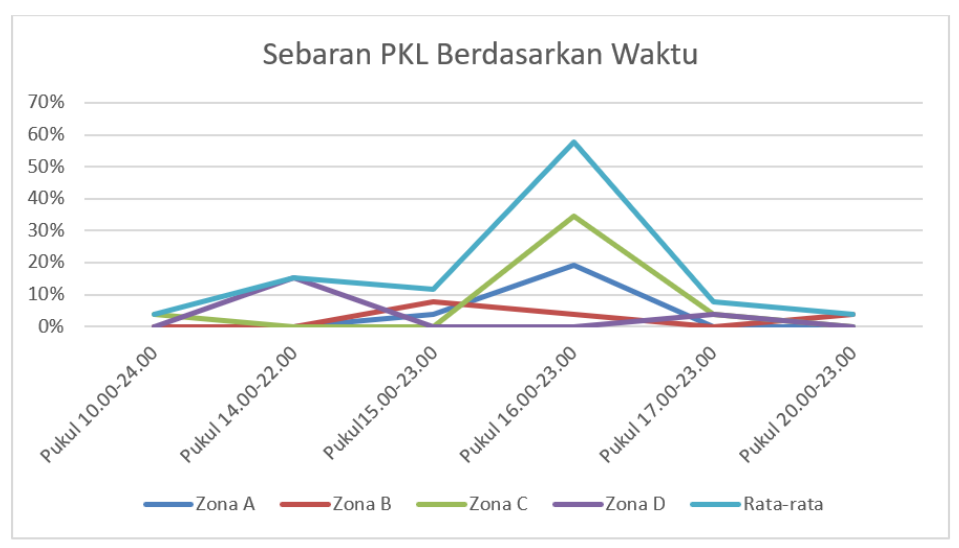

Gambar 2. Grafik Sebaran Berdasarkan Waktu Berjualan PKL

Sumber: Penulis, 2019

Kondisi cuaca dan jumlah pengunjung juga menjadi faktor lamanya para PKL berjualan, jika hujan maka waktu berjualan mereka akan lebih singkat dan saat pengunjung sudah tidak ramai mereka akan cenderung lebih singkat. Hanya terdapat satu kasus yang memulai jualan dari pukul 10.00 pagi, sebagian besar waktu berjualan didominasi di sore sampai malam hari. Secara umum para PKL berjualan hampir setiap hari dari hari senin sampai hari minggu dan jumlahnya meningkat pada akhir pekan, terutama di waktu sore hari sabtu dan minggu.

\section{Setting Ruang Sebaran PKL}

Berdasarkan hasil pengamatan sebaran PKL pada setting waterfront dari zona A-D didapatkan data sebagai berikut:

Tabel 4. Teritori Sebaran PKL Zona A, B, C, D

\section{Teritori PKL}

1) Zona A, teritori PKL pada zona, relatif tersebar di sekitar plaza utama dengan jumlah PKL masing-masing titik terdiri dari 1 sampai 3 PKL yang berjualan di menggunakan setting bangku taman yang sifatnya FIX, dan di atas 5 PKL untuk yang menggunakan pagar sisi darat (setting fix) waterfront.

2) Zona B didominasi PKL dengan jumlah 3-5 PKL yang berkelompok disisi pagar darat (setting fix) waterfront. 


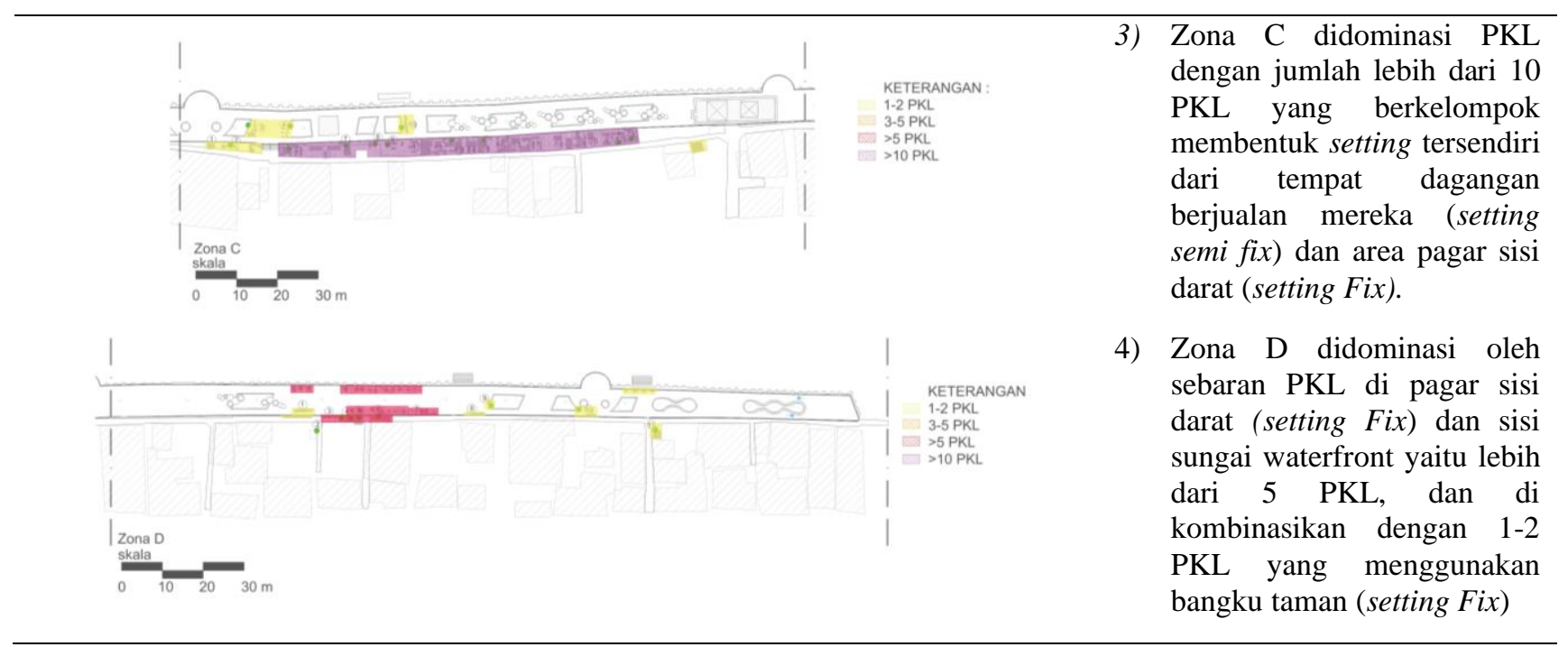

Sumber: Penulis, 2019

Berdasarkan data tersebut sebaran PKL tertinggi adalah di Zona $\mathrm{C}$ yaitu terdapat $\pm 16 \mathrm{PKL}$ yang menggunakan setting Fix sisi pagar darat waterfront dan seting semi fix yaitu dari seting area berjualan (gerobak, meja, dan kursi). Untuk zona B dan D terjadi pembentukan ruang secara berkelompok terlihat terjadi pemusatan aktivitas PKL di sekitar setting fix seperti pagar waterfront, sementara untuk PKL di zona A sifatnya masih tersebar pada area plaza dan menggunakan setting semi fix yang mereka gunakan untuk berjualan seperti gerobak dan mainan sewa.

\section{Analisis Setting Ruang}

Berdasarkan hasil analisis dapat dikelompokkan menjadi beberapa pola setting PKL di ruang terbuka Waterfront Kota Pontianak yaitu :

\section{Pola I}

Pola I, terdiri dari PKL sewa mainan dan penjual minuman dan makanan ringan, keberadaan mereka lebih menyesuaikan dengan kondisi setting ruang terbuka yang telah ada, yaitu mereka menempati bangku taman (elemen fix) yang sudah ada dan meletakan barang dagangan/sewa mereka di sekitar bangku tersebut, kepemilikannya lebih bersifat individu. Upaya untuk melakukan Personalisasi perubahan terhadap seting tidak dilakukan. Dalam mempertahankan teritorinya mereka tidak perlu melakukan penanda teritori. Upaya pemenuhan terhadap kebutuhan ataupun perlindungan terhadap cuaca tidak terjadi, hal tersebut dapat dilihat pada gambar $3 a$ dan $3 b$.
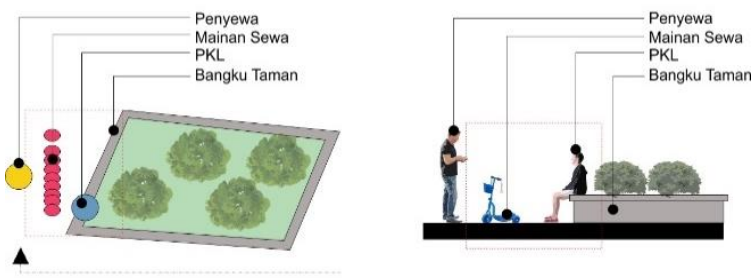

a. PKL Sewa Mainan
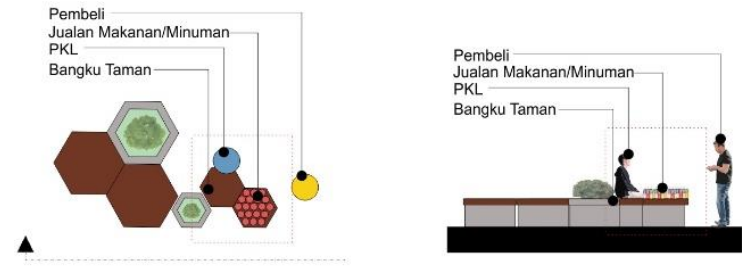

b. PKL Jualan Makan

Gambar 3. Pola I Sebaran Teritori PKL

Sumber: Penulis, 2019 


\section{Pola II}

Pola II, terdiri dari PKL yang sifatnya mobile atau tidak menetap mereka muncul di setting lebih fleksibel, mereka menempati elemen fix seperti area plaza ataupun area parkir yang kosong, kepemilikannya bersifat individual upaya personalisasi seperti penanda tidak muncul pada seting ruang terbuka tetapi diletakan menjadi bagian tempat berjualan. Elemen semi-fix yang muncul adalah barang dagangan dan box jualan. Upaya mempertahankan setting tidak terjadi seperti jejak fisik pada setting ruang terbuka. Upaya pemenuhan kebutuhan misalnya terhadap cuaca tidak terjadi, kondisi tersebut dapat dilihat pada gambar 4a dan 4b.
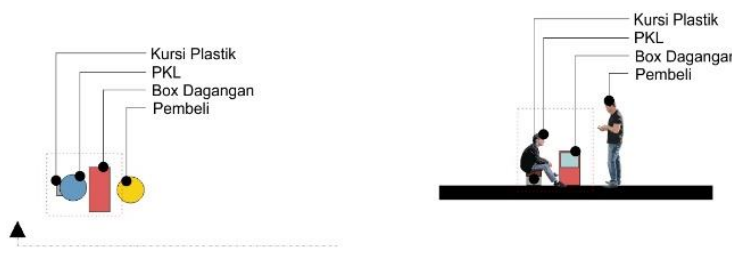

a. PKL Jualan Dengan Gerobak Jinjing
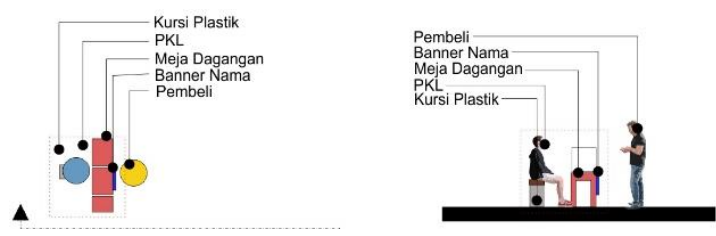

b. PKL Dengan Bangku Meja Portable

Gambar 4. Pola II Sebaran Teritori PKL

Sumber: Penulis, 2019

\section{Pola III}

Pola III merupakan PKL yang berjualan seperti makanan, gorengan, sosis bakar, bakwan dan minuman. Secara Kepemilikan didominasi secara berkelompok dan beberapa secara individual. Pada pola III elemen setting yang cukup berpengaruh adalah pagar pembatas waterfront baik disisi darat maupun di sisi sungai. Di Pola III upaya personalisasi mulai terlihat dengan jelas, masing-masing PKL memberi nama tempat mereka berjualan dengan menempelkan banner pada pagar ataupun pada bagian atas gerobak jualan mereka. Dalam upaya mempertahankan teritorinya para PKL meninggalkan setting semi fix berupa berjualan mereka seperti gerobak, meja ataupun kursi kayu. Pada pola III menunjukkan suatu batasan teritori PKL terbentuk sangat jelas dan tegas. Dan upaya untuk pemenuhan kebutuhan ataupun perlindungan terhadap panas dan hujan beberapa menggunakan terpal yang lebar untuk melindungi area berjualan, kondisi tersebut dapat dilihat pada gambar 5a, 5b, 5c.
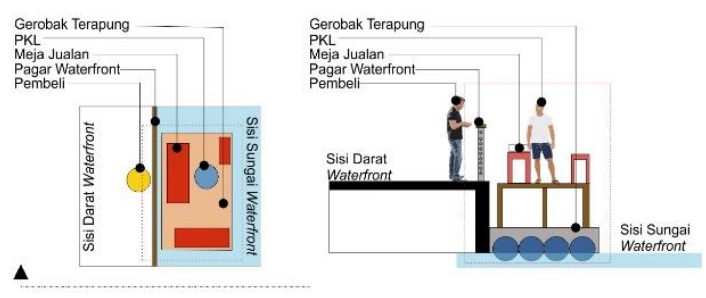

a. PKL berjualan disisi sungai dengan sampan
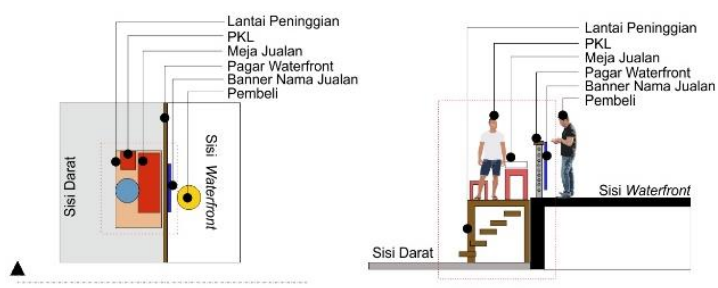

b. PKL disisi darat dengan menempel pagar waterfront 


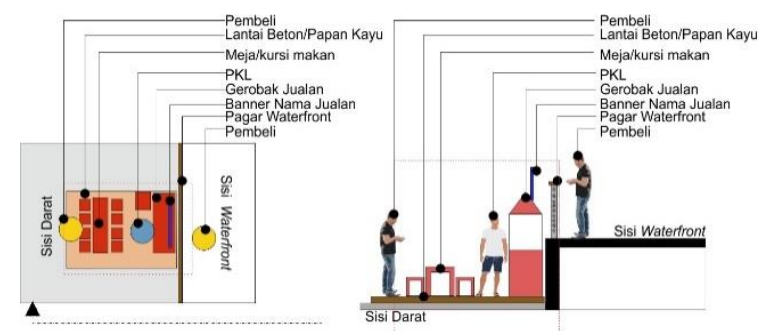

c. PKL Disisi darat dengan menggunakan bangku dan meja untuk makan pengunjung

Gambar 5. Pola III Sebaran Teritori PKL Sumber: Penulis, 2019

\section{Pola IV}

Pola IV, untuk pola ke IV hanya ditemukan satu kasus, walau hanya 1 kasus namun dapat mewakili kemungkinan dimasa yang akan datang akan muncul kasus yang serupa. Pada pola ke IV adalah PKL meletakan barang jualan berupa mainan yaitu sepanjang relling tangga naik (elemen Fix). Penggunaan elemen semi-fix yang terjadi adalah PKL menggunakan sepeda motor untuk dudukan lapak berjualan, kondisi tersebut dapat dilihat pada gambar 6

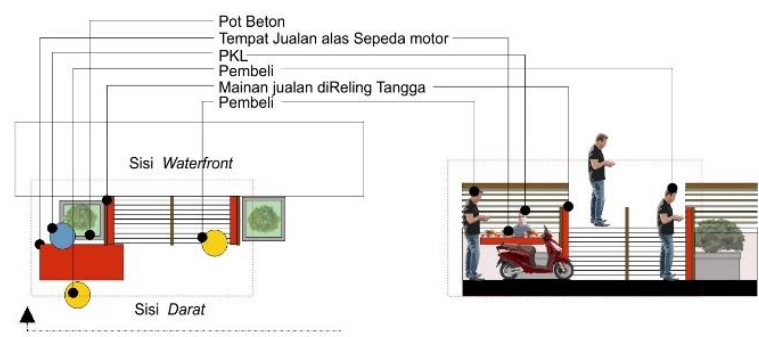

Gambar 6. Pola IV Sebaran Teritori PKL Sumber: Penulis, 2019

\section{Pola V}

Pola V, ditempati oleh PKL yang datang dari luar ataupun PKL yang sebelumnya berjualan dari tempat lain lalu mampir/berhenti ke Waterfront Seng Hie pada malam hari. Para PKL ini sifatnya lebih fleksibel. Mereka cenderung tidak masuk ke dalam hanya sampai sekitar area gerbang waterfront dan setting yang digunakan yaitu anak tangga gerbang masuk waterfront sebagai area berduduk. Personalisasi tidak terjadi, mempertahankan teritori hanya berdasarkan kesepakatan sesama PKL dan upaya pemenuhan kebutuhan tidak terjadi, kondisi tersebut dapat dilihat pada gambar 7.

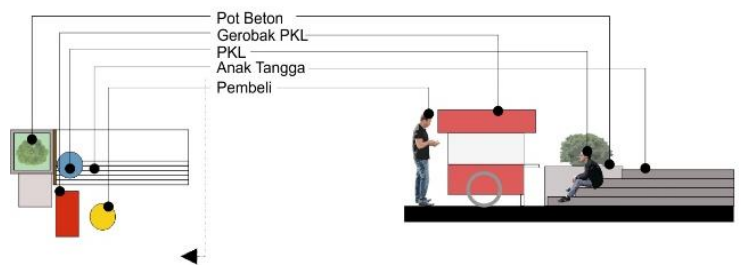

Gambar 7. Pola V Sebaran Teritori PKL

Sumber: Penulis, 2019 


\section{Kesimpulan}

Berdasarkan hasil analisis dapat ditarik kesimpulan yaitu : Faktor utama pembentuk Teritori PKL di Ruang Terbuka Waterfront Kota Pontianak dipengaruhi oleh adanya keberadaan elemen Fix seperti Pagar waterfront, bangku taman, dan perkerasan beton, dan Reling Pagar. Sedangkan elemen non-Fix secara eksisting tidak ditemukan tetapi menjadi elemen yang muncul akibat dari upaya pemenuhan kebutuhan PKL untuk berjualan di ruang terbuka yaitu munculnya keberadaan perabot dan pelengkap berjualan seperti meja, kursi dan gerobak jualan dan elemen ini sekaligus menjadi pembatas teritori antar PKL pada setting ruang terbuka. Faktor Non-Fix yaitu kedekatan dengan rumah menjadi salah satu penentu letak teritori berjualan PKL di Waterfront Kota Pontianak. Dan Pola Sebaran PKL sendiri dapat di bedakan menjadi lima pola sebaran teritori yaitu: (1) di sekitar bangku taman, 2) di sekitar plaza, 3) di sekitar pagar, 4) di sekitar railing tangga, 5) di sekitar anak tangga.

\section{Daftar Acuan}

Bell, P.A. (1996). Environmental Psychology. Environmental Psychology. Texas, United Stated : Harcourt Brace College.

Ching, D.K. (2000). Arsitektur Bentuk, Ruang, dan Tatanan. Jakarta, Indonesia : Erlangga.

Echols, Jhon M. (2005). Kamus Inggris Indonesia: An English-Indonesia. Jakarta, Indonesia: Gramedia.

Hariyadi (2010). Arsitektur, Lingkungan dan Perilaku: Pengantar ke Teori, Metodologi dan Aplikasi. Yogyakarta, Indonesia : Gadjah Mada University Press

Lang, J. (1987). Creating Architectural Theory: The Role Of Behavior Sciences in Environmental Design. New York, United Stated: Van Nostrand Reinhold.

Laurens, J. (2004). Arsitektur Dan Perilaku. Jakarta, Indonesia: Grasindo.
Rapoport, Amos. (1982). The Meaning Of Build Environment: A Nonverbal Communication Approach. California, United Stated : Sage Publications.

Soesanti, S. (2006). Pola Penataan Massa Ruang Terbuka Pada Perumahan Waterfront. Jurnal Dimensi, 34 (2), 115-121

Suprijanto, I. (2003). Kerentaan Kawasan Tepian Air Terhadap Kenaikan Permukaan Air Laut : Kasus Kawasan Tepian Air Kota Surabaya. Jurnal Dimensi, 31 (1)

Trancik, Roger. (1986). Finding Lost Space. New York, United Stated : John Wilew \& Sons.

Perda Kota Pontianak. (2013). Perda Nomor 2 Tahun 2013: Rencana Tata Ruang Wilayah Kota Pontianak Tahun 2013-2033. Pontianak, Indonesia: Sekretaris Daerah Kota Pontianak. 